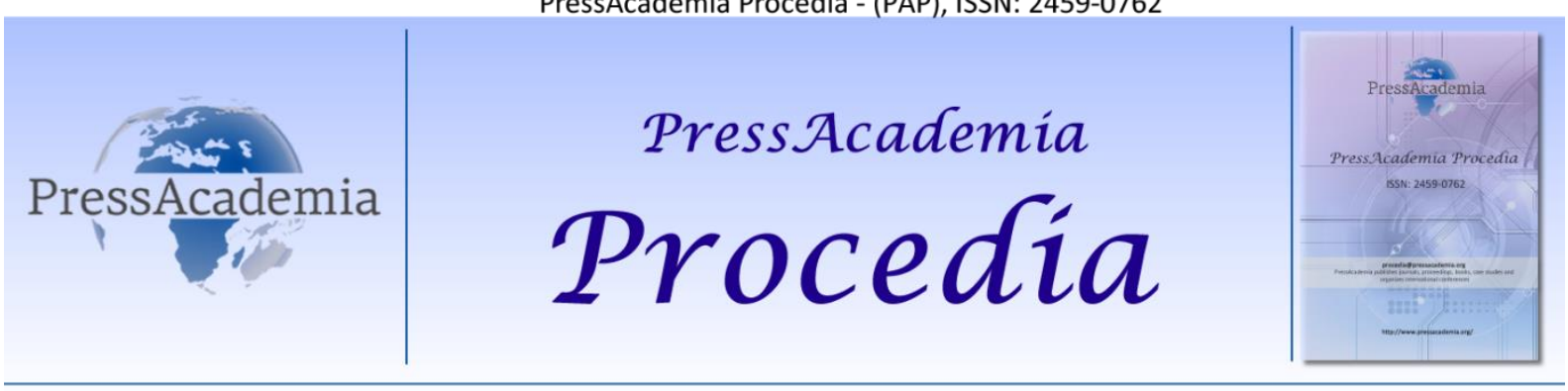

2nd World Conference on Technology, Innovation and Entrepreneurship

May 12-14, 2017, Istanbul, Turkey. Edited by Sefer Şener

\title{
ORGANIC AGRICULTURE PRACTICES IN TURKEY AS A VALUE CHAIN CREATING MODEL OF AGRICULTURAL PRODUCTION
}

\section{DOI: 10.17261/Pressacademia.2017.510 \\ PAP-WCTIE-V.4-2017(2)-p.11-19}

Murat Cetin ${ }^{1}$, Gonca Yilmaz ${ }^{2}$

${ }^{1}$ istanbul Üniversitesi, mcetin@istanbul.edu.tr

${ }^{2}$ istanbul Gelişim Üniversitesi, goyilmaz@gelisim.edu.tr

\begin{abstract}
This study emphasises the importance of promoting organic agriculture activities which will contribute to reviving and bringing the agricultural sector of Turkey to a level that is in keeping with the country's farming assets such as its land, natural resources and diversity of living organisms in the soil and also contribute to the monetary added value created in the country, which unfortunately has yet to achieve reaching contemporary development goals despite being described as a country of agriculture. The main area of focus of this study, which puts the organic farming community of Kırtık Village at the center, is the mechanism whereby all products and semi-products produced in this village are directly supplied to producers and consumers; creating an organic chain. Ensuring the fair dissemination of wealth created by the monetization of organic farming products; contributing to public health by promoting organic product awareness and increased consumption of organic products at more reasonable prices, and creating opportunities for conducting agricultural practices in a sustainable environment as a model that creates a value chain in Turkish agricultural production are the topics focused on in this study.
\end{abstract}

Keywords: Organic agriculture, organic farming, organic production, organic foods, organic bread, sustainable ecosystems JEL Codes: M10

\section{INTRODUCTION}

Turkey is ranked 14th (EIU 2016: 5) on the Economist Intelligence Unit Index which lists countries according to their agriculture sustainability, water footprint, pesticide and fertilizer usage, land ownership rights, sustainable agricultural systems, biodiversity and farmer demographics. The index is based on 1500 strings of data obtained from the World Bank, the Food and Agriculture Organization of the United Nations, Organisation for Economic Co-operation and Development (OECD) and similar agencies (EIU 2016: 14).

In the nutrition problems category, which includes headings such as the ratio of overweight and obese individuals to the general population or figures on undernutrition, insufficient child development, Turkey is ranked 19th (EIU 2016: 22). The country is ranked 20th among 25 countries, when it comes to food waste (EIU 2016: 38).

The facts expressed in the findings of the Economist Intelligence Unit Fixing Food research, regarding Turkish agriculture, are as follows:

- When compared to the developed world, vast majority of man power is in the farming industry, in opposition with the requirements of the times

- Calcified soil, soil loss due to erosion

- Soil in existing agricultural fields lose infertility, fertilizing only low-value products, due to uninformed and uncontrolled usage

- Unwanted agricultural produce (fruits and vegetables) are often rejected by export markets are sent back. They are then consumed in the domestic market which contributes to higher numbers of cancer cases. 
International indices show that, Turkey has regressed in the following areas in the recent period (Pamuk 2014: 297).

- Biological diversity, and protection of ecosystems

- Impacts of the inputs and technologies on the environment used in the agricultural sector

- Development of clean and renewable energy resources

Turkey has opened up its most fertile fields for industrialization and urban development and it has fallen into a state where it needs to import wheat to feed its domestic population, from being a land of agriculture in the past. However, in spite of the bleak picture summarized above, today it seems there is a chance to take back farming fields, to add value to affordable products, to empower farmers and encourage them to produce better quality products and to provide consumers healthier fruits and vegetables at affordable prices. As part of this study, agriculture producers are encouraged to produce organic products with high added value that will enrich them, while create an opportunity to expand organic fields and at the same time making affordably priced and healthy food available for consumers. Good agriculture practices will come out of the Kırtık Village Organic Cafeteria Project as an example of an organic chain.

\section{THE IMPORTANCE OF ORGANIC AGRICULTURE WITHIN THE SCOPE OF CURRENT PROBLEMS OF TURKISH AGRICULTURE}

\subsection{From Land of Agriculture to Wheat Importer}

In 2005, a quarter of the Turkish population was employed in agricultural sector. In 2016 this figure had decreased to 18.3\% (TUIK, 2016). For many years Turkey was considered "a farming nation" because of the weighted ratio of the agricultural sector within the economy, and again for several years the country was known as a "self sufficient" (NTV, 2016) country in agriculture.

Especially in recent years, the opinion that Turkey is a land of agriculture doesn't reflect the reality judging by the industry's weighted ratio in the economy, its added value; the level of product quality, and based on comparisons on with other countries.

The percentage of the workforce employed in agriculture in European Union is around 4\%. This figure has in Turkey lately decreased below $20 \%$ but the sector's contribution to national income is only around $7 \%$ (GTHB, 2017). An oft-quoted analogy in the past years has been the situation The Netherlands, which is only as large as the surface are of Konya province with a population of 17 million. The Netherland's 2016 agricultural exports volume stood at EUR 85 billion (GN, 2017). Turkey's exports in the same period stood at only EUR 17 billion (TIM, 2017). It should also be recalled that Turkey's population is 80 million. These figures present striking evidence as to the unproductiveness of Turkey's farming industry.

Regarding the agriculture industry, another expression used to describe Turkey is that it's a "giant granary." On the contrary, Turkey imported 44,458 tons of wheat between the first month of 2008 and May 2009 (Radikal, 2009). In January 2017, Turkey announced a series of international tenders for importing wheat from EU countries (Hürriyet, 2017). This applies not only to wheat, but to many other grains, vegetable oils, fruit and vegetable seeds and even livestock. Turkey today is an importer in all of these categories. In addition to this situation, a significant amount of products often has to be recalled due to residual pesticide.

A study by the Akdeniz University's Food Security and Agricultural Research Center at local food markets in Antalya found that in 201421 percent of 400 vegetable and fruit items contained pesticide residue (Cumhuriyet, 2015) that exceeded legislative limits. 25 percent out of 309 fruit and vegetable items in 2013 contained pesticide residue above the limit set in national regulations. It can be stated that the frequent rejection of Turkey's exported goods by its major importing partners seems to confirm the findings of this study. In recent years, in addition to political tension between the two countries, Turkish many batches of fresh fruit and vegetable exports to Russia have been returned on the grounds that the products were in violations of Russia's health legislation standards and that the produce contained fruit flies. Turkey's fruit and vegetables exports falling from USD 875 million to USD 331 million (Ulker, 2017) (a 62 percent fall) in 2016 has not been only a commercial loss. It has also contributed to increase in the frequency of several diseases, particularly certain types of cancer, as most of the rejected produce is consumed domestically (Milliyet, 2017).

The problems plaguing Turkish agriculture such as the use of GMOs or the loss of 4 million hectares of agricultural land in the past 27 years (Hürriyet, 2017), are no longer problems that only concern farmers. These have now become issues that pose a major threat to the country's habitat, its economy and general consumer health.

Agricultural fields in Turkey in general consist of several tiny parcels belonging to a number of proprietors; a situation stemming from the country's inheritance laws. This dispersed structure of agricultural fields increases production costs while impoverishing the farmers; (Boztoprak, Demir, Coruhlu 2016, 75-86) hinders the application of modern farming methods (Boztoprak vd. 2016), and prevents the diversification of transportation routes, which in turn decreases the farmers' competitive power in global markets. Land consolidation (GTHB, 2015) policies are being implemented in recent 
years, but these have not achieved a significant improvement yet. Converting carbon dioxide from greenhouse contaminants into productive elements; (Rifkin 2015: 86-87) creating new agricultural products that rely on cooperation between computer and genetic technologies (Schwab 2016, 76) seem to be the only way to live up to the necessities of the age of the Fourth Industrial Revolution. Unless such measures are taken, the gap between Turkish agriculture and developed countries will continue to expand.

\subsection{From Conventional Agriculture to Organic Agriculture}

The rapid growth of the global population has necessitated the development of new methods and technologies to increase agricultural production. The increase in agricultural productivity has been made possible by the employment of several industrially produced agricultural inputs (synthetic fertilizers, synthetic chemical pesticides, etc.) in large amounts. However, this method -- commonly referred to as conventional agriculture-- has had a negative impact on the environment with chemical residues also contaminating underground water resources. This has now reached an extend threatening the well-being of all species (ITO 1999: 1).

Therefore, in recent years the interest in bolstering productivity in agriculture, has focused on concerns regarding good agricultural practices.

"Good agricultural practices" refer to "commitment to not harming the environment during agricultural production and/or not causing harm to the well-being of humans and other species; conserving natural resources, and meeting agricultural demand through safe practices that provide for sustainability and traceability" (GTHB, 2014).

"Organic farming practices" refer to "raising or producing organic produce or inputs by using the soil, water, plants, livestock and natural resources; the collection of produce from natural areas and resources and other processes whereby the end-produce meets the consumer through harvesting, slaughter, processing, grading, packaging, labeling, conservation, storage, transportation, marketing, import, exports and all other processing" (GTHB, 2010).

According to the definition of the UN Food and Agriculture Organization (FAO) organic farming, is a type of production aiming: "organic agriculture is a holistic production management system which promotes and enhances agro-ecosystem health, including biodiversity, biological cycles, and soil biological activity. It emphasises the use of management practices in preference to the use of off-farm inputs, taking into account that regional conditions require locally adapted systems. This is accomplished by using, where possible, agronomic, biological, and mechanical methods, as opposed to using synthetic materials, to fulfill any specific function within the system" (FAO, 1999).

According to European Union (EU) "organic farming is an agricultural system that seeks to provide the consumer, with fresh, tasty and authentic food while respecting natural life-cycle systems" (EU, 2017). The European Union also, as part of its "rural development plan 2014-2020" considers organic farming as an important instrument for the development of rural areas in the Union (EU, 2017).

Conventional Agriculture to prevent losses in the amount of production due to diseases and pests, has traditionally used agricultural and synthetic fertilizers to increase soil productivity, which has come to pose a significant threat not only to environment and the soil, but also the well-being of human and animal species. Organic farming, unlike the conventional agriculture, supports the ecosystem and the well being of humans and the soil (Tilman, Cassman, Matson, Naylor, Polasky 2002: 272).

According to a study on the impact of organic farming on biodiversity and productivity, organic farming practices increase biodiversity in the soil by 30 percent in comparison with conventional agriculture (Bengtsson, Ahnstrom, Weibull 2005: 265).

Considering the nature and human respecting aspects of organic agriculture, it is not difficult to assert that, organic farming will be the only choice in the future for not only farmers but also consumers, who are the most directly influenced by the diseases caused by conventional agriculture (FAO, 2004).

The use of chemicals, fertilizers, hormones used in the agricultural sector have begun to significantly affect human and public health; increasing the frequency of various types of cancer and leading to higher rates of obesity and neurological disorders (FAO, 2000).

Organic agriculture offers a system that has the highest degree of reliability due to traceability and control systems overseen by certification bodies that include controls and checkpoints at each stage of production: starting from the planting phase until the delivery stage to the end user; including during harvesting, processing, packaging, tagging, grading, storage, transportation and other processes.

Eco-farming or bio-farming-- or to use the most common expression -- organic agriculture, doesn't only have the potential to put an end to the contamination of natural resources, the soil and dissemination of toxic materials to humans and animal 
species, but it also has the capacity to foster the conservation of the livelihood and the natural biological structure of the soil, which in turn will contribute to the sustainability of soil fertility in Turkey and in the world.

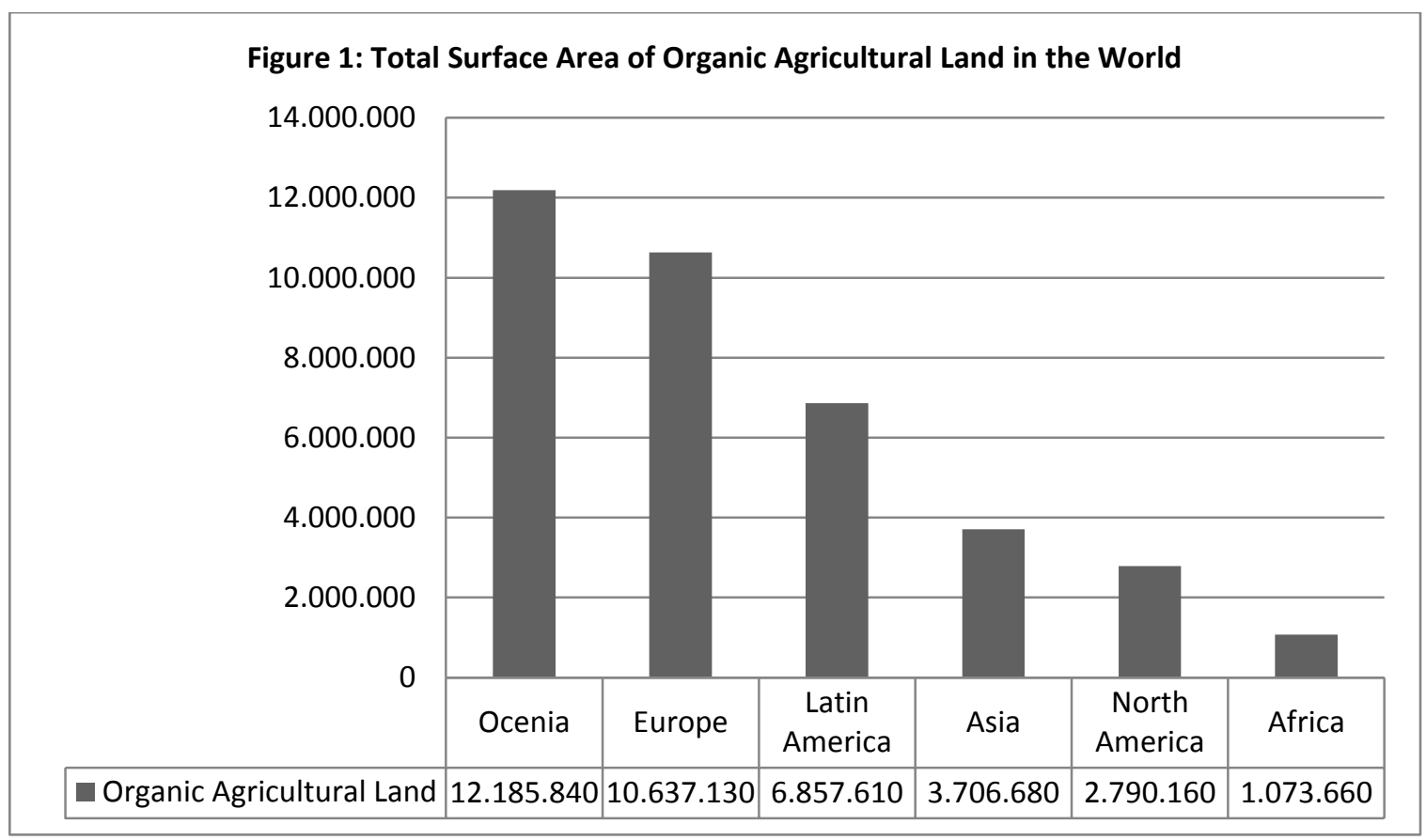

Source: Sevinç Ateş, Nevşehir District, The Impacts of Different Fertilizer and Mulch Materials which can be used in Organic Strawberries Farming on Productivity and Quality Properties, Ph.D Thesis unpublished, Adana, 2015, p.11.

According to 2014 data 1,9 million certified organic producers in 164 countries in the world used 37,5 million hectares of land for organic farming practices. Comparing this data with 2007 data shows that the number of countries that are practicing organic agriculture, has increased from 141 to 164; and the surface area allocated to organic farm has grown to 37.5 million hectares from 35 million hectares (Milliyet, 2017).

In the above chart organic agriculture fields are shown on a continental basis. According to the chart Oceania is ranked first with 12.2 million hectares of land allocated to organic farming, followed by Europe (10,6 million hectares) ,Latin America (6,9 million hectares) and Asia (3,7 million hectares).

The top three countries that have the largest organic farming lands are Australia (12 million hectares), Argentina (3,8 million hectares) and the USD (1,9 million hectares) (Ates, 2015).

According to the data from the Turkish Statistical Institute (TurkStat) the development of organic crop production in Turkey is as follows:

Table 1: Organic Crop Production

\begin{tabular}{ccccc} 
& Number of crops & $\begin{array}{c}\text { Number of } \\
\text { farmers }\end{array}$ & Area(1) & Production \\
\cline { 2 - 5 } (Number) & ( Number) & ( Hectares) & (Tonnes) \\
\hline 2005 & 205 & 14401 & 203811 & 421934 \\
2006 & 203 & 14256 & 192789 & 458095 \\
2007 & 201 & 16276 & 174283 & 568128 \\
2008 & 247 & 14926 & 166883 & 530224 \\
2009 & 212 & 35565 & 501641 & 983715 \\
2010 & 216 & 42097 & 510033 & 1343737 \\
2011 & 225 & 42460 & 614618 & 1659543 \\
2012 & 204 & 54635 & 702909 & 1750127 \\
2013 & 213 & 60797 & 769014 & 1620387
\end{tabular}




\begin{tabular}{llllc}
2014 & 208 & 71472 & 842216 & 1642235 \\
2015 & 197 & 69967 & 515268 & $1 \quad 829291$ \\
\hline
\end{tabular}

Source: Ministry of Food, Agriculture and Livestock

(1)Wild production areas are included.

Source: TÜiK, http://www.tuik.gov.tr/UstMenu.do?metod=temelist, 2.04.2017

\section{AGRICULTURAL PRODUCTION AND THE CREATION OF VALUE CHAIN}

When compared with developed economies, Turkey is still far behind the desired level in terms of producing high value added products. The percentage of high-tech commodities is only $2 \%$ in Turkey's exports while this figure is $27 \%$ in China, $18 \%$ in South Korea and Switzerland, 17 \% in USA and $16 \%$ in Japan, France, Germany and Mexico. Moreover, according to a bulletin prepared by the Antalya Chamber of Trade and Industry, while the worth of Turkish exports per kilogram was USD 1.34 in 2015, that number fell to USD 1.32 in December 2016 (ATSO, 2017).

We are faced with starker picture when we examine the dollar-worth per kilogram numbers for agricultural products. The net worth per kilo for fruit and vegetable products is USD 0.98 and that figure can be as law as USD 0.49 in the case of fresh fruit and vegetable exports ( ATSO, 2017).

Table 2: The Average Dollar Value Per KG in Turkish Exports

\begin{tabular}{|l|c|}
\hline SECTOR & $\begin{array}{c}2016 \text { December Exports } \\
\text { (kilogram/dollar) }\end{array}$ \\
\hline Ready-to-wear and garments & 14,78 \\
\hline Leather and leather products & 11,90 \\
\hline Hazelnut products & 8,09 \\
\hline Tobacco & 7,04 \\
\hline Automotive industry & 6,85 \\
\hline Machine and machinery & 5,54 \\
\hline Other industrial products & 5,19 \\
\hline Textile and textile raw materials & 4,05 \\
\hline Climatization industry & 4,15 \\
\hline Ship and yacht building & 4,14 \\
\hline Electric- electronic and services & 4,98 \\
\hline Iron and non-iron metals & 3,49 \\
\hline Carpets & 3,02 \\
\hline Dried vegetables and products & 2,79 \\
\hline Olive and olive oil & 2,34 \\
\hline Water products & 2,15 \\
\hline Ornamental plants and products & 2,18 \\
\hline Furniture and paper products & 1,31 \\
\hline Fruit and vegetable products & 0,98 \\
\hline Chemicals and chemical products & 0,83 \\
\hline Cereals and products & 0,75 \\
\hline Fresh fruits and vegetables & 0,49 \\
\hline Steel & 0,57 \\
\hline Mining products & 0,22 \\
\hline Cement, glass and soil products & 0,15 \\
\hline
\end{tabular}

Source: Antalya Chamber of Commerce and Industry http://www.atso.org.tr/detay/2/5/1/5309/atso-subat-ayi-meclis-konusmasi.html, 11.03.2017.

As the striking figures from the Antalya Chamber of Commerce indicate, Turkey, which has to export 2.7 tons of mining 
products per a mobile phone imported at USD 600, is getting behind in completing the transition to becoming a country where it exports processed commodities instead of exporting natural resources without any industrial processing.

Creating a global value chain, producing high value-added products that have become brands, and conducting farming activities employing a technological infrastructure in line with the necessities of the Information Age is an imperative that needs to be fulfilled, albeit belatedly. At this point, two successfully implement value chain examples from the FAO provide sufficient clues for how Turkey can achieve its own transformation.

"According to FAO, sustained value chains ensure economic sustainability by creating added value; social sustainability by encouraging fairer distribution of the created added value and environmental sustainability by reducing the ecological footsteps" (Erol 2015: 43).

The first of the examples is the "Indian Potato Value Chain", which includes changing the type of crop used in horticultural production. When PepsiCo needed a different type of potato for its Frito Lay's, potato farmers started producing a new type of potato which was better fit for chips production, although the switch increased their costs by 20 percent. This way, the farmers' profit rose by between 10 to 50 percent (Erol 2015: 45) in comparison with their traditional farming practices.

The second example of a successful value chain is from Central America: A group of US coffee buyers founded small enterprises and cooperatives for the production of high quality coffee beans. The scheme secured good coffee for consumers and contributed to exports of the countries involved. The scheme also led to the creation of many new jobs and conservation of the environment thanks to the use of environmentally friendly farming methods. The Project, which started with 3000 selected producers in 2003, had reached to include 6000 producers in 2009 (Erol 2015: 46).

\section{KIRTIK VILLAGE ORGANIC CAFETERIA PROJECT}

As in the success story of the Central America coffee value chain, the Organic Cafeteria Project for Kırtık Village aims to achieve the creation of a value chain by using a similar approach through establishing direct consumer-producer and producer producer links, in a relationship where the two sides will mutually foster each other.

It is of importance that one of the most well-established economics departments in Turkey, the Istanbul University's department of economics supports this project which focuses on the expansion of organic agriculture areas and increasing supply of affordable organic food.

The project was launched in July 2015 , in order to support over fifty certified organic producers of Kırtık Village, located in the Burhaniye district of Balıkesir province.

The project initially consisted of supporting marketing efforts of individual farms, advertisement of their products, the creation of a website (Kırtık, 2017) to this purpose and the managing of social media accounts. It has now reached a point where its focus on now complete commercialisation of the organic agricultural products -- the unprocessed raw resource -by branding and creating added value.

\subsection{Purpose Of The Project}

While the one arm of the project seeks to encourage local farmers to produce branded, functional and value added products to increase their incomes (and as such contribute to the expansion of land used for organic agriculture), another arm of the project focuses on improving public health by making available affordable and healthy foods through the efforts of producers, and contributing to the expansion of organic produce. The third element in the project, production of organic bread, will contribute to the producer-consumer chain.

Increased level of welfare, due to branded and commercialized quality products, will lead to higher contribution of the agricultural sector to the economy. Higher income levels will not only motivate the farmers to produce more organic, but they will also eliminate the pressure of migration to cities.

On the contrary, migration to villages will change organic agricultural areas; turning them into centers of attraction. We will likely see a considerable increase in employment in the region. .

The development of organic production motivated by the raised income levels caused by branded products which are ready to compete in foreign markets, will not only lead to soil conservation; water quality and energy conservation; higher biological diversity (Allen, Kovach 2000, 223) but it will also positively contribute to improving public health as the most important incentive among the "ten reasons to consume organic foods" (Boyacioglu, 2002) as listed by the Organic Consumers Association.

\subsection{Phases of the Project}

The project has first focused on production, rather than selling products by promising minimum purchase quotas. 
Subsequently, the organic fields which are only used in the summer will be prevented from staying idle, which will allow the production of new crops, which in turn will ensure full capacity usage of organic fields and also provide additional income to farmers.

Bread has a special place in Turkish cuisine. Due to an increase in the use of genetically modified wheat and additive agents and preservatives, bread consumption is increasingly threatening public health (Boyacıoglu, 2002). For this reason, bread will play an important role in encouraging people to get into the habit of feeding organically, and later in maintaining that habit. To this end, through interaction bakeries producing bread from non-GMO organic wheat and employing traditional sourdough (probiotic) methods; cakes, muffins, and other snack foods will be produced and sold at reasonable prices, particularly in school cafeterias.

The organic bakery, which comprises the third phase of the project, will also have the role of a ready market, in which the certified organic products, primarily olive oil, produced in the organic village will be marketed.

Academics will be in the first target audience for marketing of the products, considering this group's income level and awareness of organic eating. Academic staff will be informed via e-mails and brochures about the assortment, which they will be able to order online. Students working in the project on a part time basis will meet their orders.

The most important stage of the project is the construction of a dehydration to enable the storage, transportation and subsequently the commercialization of organic raw foods. The building constructed by Burhaniye Municipality in the village for this purpose, will be furnished with vegetable-fruit slicing machines, as well as dehydration equipment and packaging facilities.

Following this phase, an olive oil plant will be constructed for squeezing olives and bottling of the olive oil; another major product of the village.

Later on, the brand which will be created will carry the location label and the name of the village, which will help jumpstart rural tourism in the village. With this purpose, in order initiate organic tourism, bungalows will be erected in the subject field which will be leased from the Ministry of Forestry. The visitors who join tours of the village will be given information about organic agriculture and shown the activities. The income earned will go to seasonal agricultural training and sports activities for students and the disabled.

In the future phases of the projects, one of the plans is to help neighboring villages transition to organic farming with the organic chain starting to function, in order to help expand the area of organic fields and to ensure that these villages are also included in the chain. Funds that will be derived from income earned from organic activities will be used to this end. Farmers from the newly included villagers will attend training and later practice farming in the Kırtık village, during which the participants will be supported financially by means of the above mentioned funds. The organic chain, ever growing with the inclusion of more new villages, will eventually contribute significantly to achieve rural development.

\section{CONCLUSION}

This study focuses on a project, which was developed to overcome the difficulties stemming from recession felt in every facet of Turkish agriculture, despite the country's misleading fame as a country of agriculture. The project includes activities to reverse the recession in agriculture by encouraging organic farming efforts; helping to restore the health quality of produce (which has significant adverse effects on public health), eliminating factors that degrade soil, water, air quality and biodiversity and by contributing to sustainability of the environment.

The village of Kırtık, in Balıkesir, Burhaniye-- the location of the Organic Cafeteria Project where fifty certified organic farmers participate -- will likely become the biggest organic village of Turkey. By establishing a fruit and vegetable processing facility and distributing the dried and packaged produce as affordable and nutritious snacks first to students and staff healthy; the project seeks to eventually extend the organic chain to a wider population with the creation of organic sales points.

\section{REFERENCES}

Allen P. and Kovach M., The capitalist composition of organic: The potential of markets in fulfilling the promise of organic agriculture, https://pdfs.semanticscholar.org/76d3/6b1d50febce8ff968e38d2858d25d0906c51.pdf, p.223, 2.04.2017

Allen P. and Kovach M., The capitalist composition of organic: The potential of markets in fulfilling the promise of organic agriculture, https://pdfs.semanticscholar.org/76d3/6b1d50febce8ff968e38d2858d25d0906c51.pdf, p.223, 2.04.2017

Antalya Chamber of Commerce and Industry, http://www.atso.org.tr/detay/2/5/1/5309/atso-subat-ayi-meclis-konusmasi.html , 24.02. 2017

Ateş, Sevinç, Nevşehir District, The Impacts of Different Fertilizer and Mulch Materials which can be used in Organic Strawberries Farming on Productivity and Quality Properties, Ph.D Thesis unpublished, Adana, 2015, p.10. 
Ateş, Sevinç, Nevşehir District, The Impacts of Different Fertilizer and Mulch Materials which can be used in Organic Strawberries Farming on Productivity and Quality Properties, Ph.D Thesis unpublished, Adana, 2015, p.11.

Avrupa Birliği, Agriculture and Rural Development, http://ec.europa.eu/agriculture/rural-development-2014-2020/index_en.htm, 06.04.2017.

Bengtsson J., Ahnström J., and Ann-Chrıstın Weıbull A.C., The Effects Of Organic Agriculture On Biodiversity And Abundance: A MetaAnalysis, http://onlinelibrary.wiley.com/doi/10.1111/j.1365-2664.2005.01005.x/pdf, s.265, 06.04.2017.

Boyacıoglu, M. Hikmet, Bazı un katkı maddeleri ve bunlara ilişkin ülkemizdeki son gelişmeler, http://www.tekbas.com.tr/images/resim/makale1.pdf , 2.04.2017

Boztoprak T, Demir O , Çoruhlu Yakup E., Problems Regarding the Land Consolidation Practices Sourced by Legislation and Solution Suggestions, Electronic Cartography Technologies Bulletin Cilt: 8, No: 1, 2016 (75-86), http://s3.amazonaws.com/academia.edu.documents/45198924/YAYINLANAN_MAKALE.pdf?AWSAccessKeyId=AKIAIWOWYYGZ2Y53UL3A\& Expires=1491338339\&Signature=QFiutoURXOWkPIm6OMA\%2Frc\%2BwqFU\%3D\&response-contentdisposition=inline\%3B\%20filename\%3DArazi_Toplulastirmasi_Uygulamalarinda_Me.pdf, p.76, 23.03.2017.

Cumhuriyet Gazetesi, 5 Temmuz 2015, http://www.cumhuriyet.com.tr/haber/turkiye/314463/Meyvemizi_bile_zehir_ettiler.html, 23.03.2017.

Erol Elif M., An Evaluation on Supply and Value Chain in Globalized World, T.C. Gıda Tarım ve Hayvancılık Bakanlığı, Uzmanlık Tezi, Ankara, 2015, p.43.

Erol Elif M., An Evaluation on Supply and Value Chain in Globalized World, T.C. Minestry of Food, Agriculture and Livestock, Uzmanlık Tezi, Ankara, 2015, p.45.

Erol Elif M., An Evaluation on Supply and Value Chain in Globalized World,, T.C. Minestry of Food, Agriculture and Livestock, Uzmanlık Tezi, Ankara, 2015, p.46.

EU , What is organic farming?, https://ec.europa.eu/agriculture/organic/organic-farming/what-is-organic-farming_en, 06.04.2017.

FAO, Childhood Pesticide Poisoning Information for Advocacy and Action, http://www.fao.org/newsroom/common/ecg/51018/en/maquette_childhood.pdf, 06.04.2017.

FAO, Food Safety And Qualıty As Affected By Organıc Farmıng, http://www.fao.org/docrep/meeting/X4983e.htm\#b1, 06.04.2017.

FAO, Organic Agriculture, http://www.fao.org/docrep/meeting/X0075e.htm, 06.04.2017.

Hollanda Ekonomi Bakanlığı, https://www.government.nl/latest/news/2017/01/20/agri-food-exports-achieve-record-high-in-2016, 23.03.2017

Gıda Tarım ve Hayvancılık Bakanlığı, http://www.tarim.gov.tr/Belgeler/ButceSunumlari/2017_Yili_ButceSunumu.pdf, 21.03.2017.

Hürriyet Gazetesi, 11 Ocak 2017, http://www.hurriyet.com.tr/turkiye-abden-bugday-alacak-40332978, 23.03.2017.

Hürriyet Gazetesi, 3 Ocak 2017, http://www.hurriyet.com.tr/27-yilda-4-milyon-hektar-tarim-alani-yok-oldu-40325168, 23.03.2017.

İstanbul Ticaret Odası, “Dünya'da ve Türkiye'de Ekolojik Tarım Ürünleri Üretimi, İhracatı ve Geliştirme Olanakları”, iTo yayınları, Yayın No: 1999-70, Aralık 1999 İstanbul, p. 1.

Kırtık Organik, http://www.kirtik.com/, 2.04.2017

Milliyet Gazetesi, "Yükte Ağır, Pahada Ucuz Ürünler İhraç Ediyoruz", http://www.milliyet.com.tr/yukte-agir-pahada-ucuz-urunler-ihracantalya-yerelhaber-1863836,24.02. 2017

Milliyet Gazetesi, 3 Nisan 2017, http://www.milliyet.com.tr/bozulan-gidalar-kanser-saciyor--gundem-2425137/, 23.03.2017.

NTV, The lie of'Kendi Kendine Yeten Ülke' Yalanı, http://www.ntv.com.tr/ekonomi/kendi-kendine-yeten-ulke yalani,FNtrdzPAt0av9jE5ddddGQ, 13.02.2017.

Organic Consumers Association, Safeguard Organic Standards: 10 Reasons Consumers Buy Organic, https://www.organicconsumers.org/essays/safeguard-organic-standards-10-reasons-consumers-buy-organic, 2.04.2017

Pamuk, Şevket, Türkiye'nin 200 Yıllık İktisadi Tarihi, Türkiye İş Bankası Kültür Yayınları, 3. Baskı, İstanbul, 2014.

Radikal Gazetesi, 06.09.2009, http://www.radikal.com.tr/ekonomi/turkiye-bugdayda-ithalatci-ulke-oldu-953109/, 23.03.2017.

Rifkin, Jeremy, Nesnelerin İnterneti ve İşbirliği Çağı, çev. Zülfü Dicleli, Optimist Yayınları, İstanbul, 2015.

Schwab, Klaus, Dördüncü Sanayi Devrimi, çev. Zülfü Dicleli, Optimist Yayınları, İstanbul, 2016, p.76.

T.C. General Directorate of Legislation Development and Publication,

http://mevzuat.basbakanlik.gov.tr/Metin.Aspx?MevzuatKod=7.5.14217\&Mevzuatlliski=0\&sourceXmISearch=tar\%C4\%B1m, 06.04.2017. 
T.C. Minestry of Food, Agriculture and Livestock, 'Arazi Toplulaştırma ve Tarla İçi Geliştirme Hizmetleri', http://www.tarim.gov.tr/Konular/Arazi-Toplulastirma-ve-Tarla-Ici-Gelistirme/Projeler, 06.04.2017.

T.C. Minestry of Food, Agriculture and Livestock, 2017 Budget Presentation,

T.C. Ministry of Food, Agriculture and Livestock, İyi Tarım Uygulamaları Hakkında Yönetmelik, http://www.tarim.gov.tr/BUGEM/Belgeler/Bitkisel\%20\%C3\%9Cretim/\%C4\%B0yi\%20Tar\%C4\%B1m\%20Uygulamalar\%C4\%B1/\%C4\%B0TU\%2 OMevzuat/itu_yonetmelik_2014.pdf, 06.04.2017.

T.C. Ministry of Food, Agriculture and Livestock, Organik Tarımın Esasları ve Uygulanmasına İlişkin Yönetmelik,

The Economist Intelligence Unit, Fixing Food, http://foodsustainability.eiu.com/wp-content/uploads/sites/34/2016/11/Barilla-FixingFood.pdf , p.5, 21.03.2017.

The Economist Intelligence Unit, Fixing Food, http://foodsustainability.eiu.com/wp-content/uploads/sites/34/2016/11/Barilla-FixingFood.pdf, p.14, 21.03.2017.

The Economist Intelligence Unit, Fixing Food, http://foodsustainability.eiu.com/wp-content/uploads/sites/34/2016/11/Barilla-FixingFood.pdf, p.22, 21.03.2017.

The Economist Intelligence Unit, Fixing Food, http://foodsustainability.eiu.com/wp-content/uploads/sites/34/2016/11/Barilla-FixingFood.pdf, p.38, 21.03.2017.

Tilman David, Kenneth G. Cassman, Pamela A. Matson, Rosamond Naylor \& Stephen Polasky, 'Agricultural sustainability and intensive production practices', http://www.nature.com/nature/journal/v418/n6898/pdf/nature01014.pdf, p.672, 06.04.2017.

Turkısh Exporters Assembly, http://www.tim.org.tr/tr/basin-odasi-gundem-turkiye-ihracati-2017-yilinda-155-milyar-dolarayukselecek.html, https://www.gidahatti.com/tim-de-acikladi-2016-ihracati-ne-oldu-73054/, 23.03.2017.

The Turkish Statistical Institute, http://www.tuik.gov.tr/UstMenu.do?metod=temelist, 21.03.2017.

Ulker K., Dünya Gazetesi, 24 Mart 2017, http://www.dunya.com/kose-yazisi/rusya-turkiye-arasinda-gida-gerilimi/355125 , 23.03 .2017$. 